\title{
Insights into the antibiotic resistance in Biofilms - A Review
}

\author{
Jyoti Prakash Sahoo 政 \\ Department of Agricultural Biotechnology, Odisha University of Agriculture and Technology, Bhubaneswar, India
}

Ambika Prasad Mishra

Department of Soil Science, Faculty of Agriculture, Sri Sri University, Cuttack, India.

Kailash Chandra Samal

Department of Agricultural Biotechnology, Odisha University of Agriculture and Technology, Bhubaneswar, India Ashish Kumar Dash

Department of Soil Science and Agricultural Chemistry, Odisha University of Agriculture and Technology, Bhubaneswar, India

\begin{tabular}{|c|c|}
\hline ARTICLE INFO & ABSTRACT \\
\hline $\begin{array}{l}\text { Received : } 03 \text { June } 2021 \\
\text { Revised : } 01 \text { August } 2021 \\
\text { Accepted : } 11 \text { August } 2021 \\
\text { Available online: } 19 \text { November } 2021 \\
\text { Key Words: } \\
\text { Antimicrobial agents } \\
\text { Antibiotic resistance bacteria } \\
\text { Biofilm } \\
\text { Response } \\
\text { Stress }\end{array}$ & $\begin{array}{l}\text { The biofilms comprise a population of bacteria with a varying variety of } \\
\text { polysaccharides, proteins and DNA. Bacterial multi-phase defence consists of } \\
\text { low antibiotic absorption, sluggish replication in the biofilm, and adaptive } \\
\text { stress response. This antibiotic resistance produced by biofilm makes it } \\
\text { challenging to deal with bacteria with effective antibiotic dosages in planktonic } \\
\text { forms. A crucial component in the virulent colonisation of live tissues or } \\
\text { medical equipment is having favourable situation for bacteria to create } \\
\text { biofilms. The high level of recalcitrance in biofilm populations is due to several } \\
\text { molecular pathways. As the stock of effective antibiotics is depleting, bacterial } \\
\text { resistance is becoming an increasing risk to public health. As a result, new } \\
\text { antibiotics are urgently needed. This review includes current empirical findings } \\
\text { related to antibiotic resistance in biofilms and summarises the biofilm } \\
\text { resistance and tolerance mechanisms. }\end{array}$ \\
\hline
\end{tabular}

\section{Introduction}

Bacteria may create biofilms on a broad range of surfaces, including fabrics, industrial surfaces, and medical equipments (RegBott et al., 2011). It protects bacteria from dangerous environmental variables such as osmotic pressure, metal toxicity, and antibiotic exposures. In the last four decades, new tools have been developed to examine biofilms directly. The composition of bacterial populations linked to coated surfaces in a matrix of glycocalyx was initially defined as a biofilm, but not only its easily observed properties, such as attached cells to a surface or interface embedded in an extracellular polymeric matrix, have determined a true definition of the biomedical film (Gebreyohannes et al., 2019). A biofilm is sessile microbial cell culture. These cells are embedded into an extracellular polymer (EPS) matrix permanently attached to and on one surface or interface. They also regulate their growth rate and gene transcription (Wingender et al., 2016). The EPS comprises proteins, cellulose, alginates, extracellular teichoic acid and other organic compounds necessary for the formation and physical interaction of glucosamine, lipids, nucleic acids, phospholipids, polysaccharide and extracellular DNA (Jolivet-Gougeon et al., 2014). Planktonic cell attachment to the surface, cell distinction, EPS secretion, maturation and dispersion of biofilms are the stages of biofilm growth (Mangwani et al., 2016). It is separated into three stages: irreversible attachment to the surface, bacterial division and the creation of the extracellular matrix, ultimately matrices disintegration (Jamal et al., 2018). Quorum sensing (QS) is one of many species' regulatory systems for forming a biofilm illustrated in Figure 1 (Mangwani et al., 2018). Biologists looked at how biofilms become resistant to antibiotics, focusing on the biofilm matrix, physiologic heterogeneity in biofilm cells, quorum sensing, horizontal gene transfer and other alterations on the biofilm itself (Uruén et al., 2021). When 104 clinical Acinetobacter baumannii strains were tested for

Corresponding author E-mail: jyotiprakashsahoo2010@gmail.com

Doi: https://doi.org/10.36953/ECJ.2021.22307

This work is licensed under Attribution-Non Commercial 4.0 International (CC BY-NC 4.0)

(C) ASEA 
biofilm formation, bacterial resistance was examined. As a result, persister cells were shown to

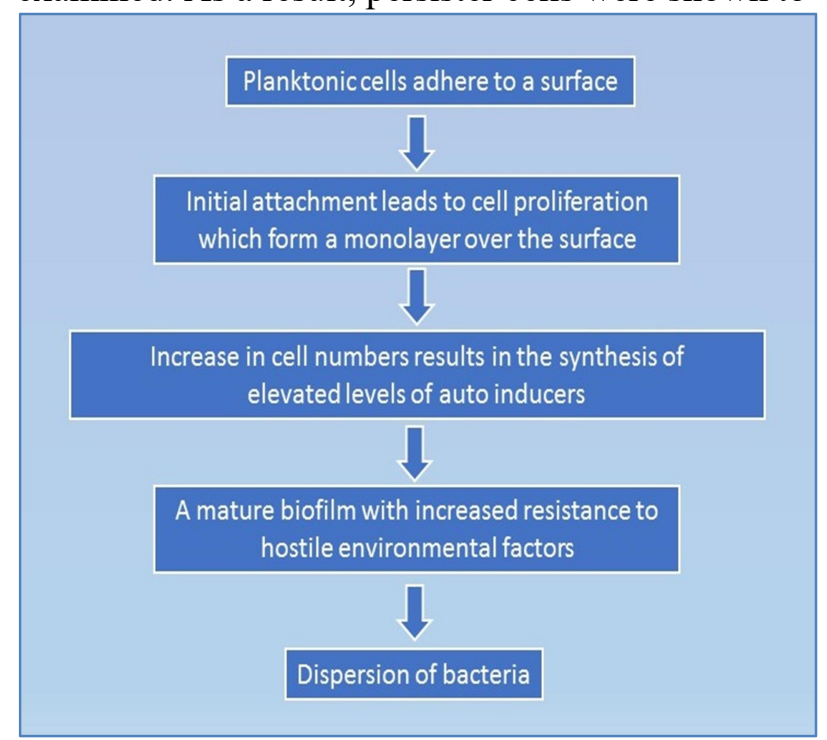

Figure 1: Development stages of bacterial biofilm

be more prevalent on biofilms when biofilmeradication concentrations were substantially greater than bactericidal concentrations for various antibiotics (Shenkutie et al., 2020). Bacteria living in biofilms are highly resistant to antibiotics and chemical disinfectants because of their metabolic state and matrix protection. There have been significant advancements in developing antibiotic alternatives or complementary methods for preventing and controlling biofilms. One of the criteria investigated was the influence of the biofilm matrix on flow cytometry in multispecies biofilms. Even though this approach can examine various characteristics of biofilms, the authors indicate that the results are highly reliant on the microbial strain employed, the morphological condition of the cells, and the biofilm matrix used in the study (Grainha et al., 2020). This review examines the role of the biofilm as a gene repository that is antibiotic-resistant and summarises the origins and consequences of extended biofilm exposition and their involvement in antibiotic resistance.

\section{Environment, biofilms and antibiotics}

A single bacterial species may create biofilms, but they often consist of a complex and varied community of bacteria, algae, fungus and protozoa, integrated into polysaccharides, exudates etc.
(Wimpenny et al., 2000). Many microbial species may modify their lifestyle depending on their physiological condition, physicochemical state, or the availability of organic matter in suspended particles and surfaces to benefit from the greater availability of organic matter (Teschler et al., 2015). Biofilms occur on benthic substrates, such as flowing pavilions, sand in aquatic ecosystems, and floating macro and micro-aggregates (Simon et al., 2002). Microorganisms participate actively in organic matter, nutrient dynamics, and biogeochemical cycle breakdown, making them essential for the ecosystem's operation (Roman, 2010). In addition, streaming biofilms are considered strong indicators of overall water quality and the ecological condition of the system (Sabater et al., 2007). Because of the increasing numbers of substances released into the aquatic bodies by waste water treatment, agricultural runoff, and by chemical compounds like metals, personal care products and medicines, which are used in veterinarians, it shall be of particular interest to assess how biofilm populations react to anthropogenic pollution of aquatics (Baquero et al., 2008).

The biofilms' length and the resistance to chemical and environmental stresses have improved in particular but not alone (Høiby et al., 2010). Bacterial cells have 10 to 1000 times less chance of having certain antimicrobials in biofilms than their planktonic counterparts (Gilbert et al., 2002). This lower sensitivity occurs from a combination of (i) inadequate insertion of an antibiotic into the matrix; (ii) resistant cells; and (iii) non-growing, chemically unfavourable cells inside the biofilm matrix that have produced stress (Stewart, 2002). The protection mechanisms operate synergistically to strengthen the overall resistance from biofilms to antimicrobial chemicals with those responsible for conventional resistance in bacterial genomes. For example, $\beta$-lactamase-generative bacteria have more protection in biofilms since $\beta$-lactam antibiotics such as ampicillin have inactivated these $\beta$-lactamases (Anderl et al., 2000). Furthermore, sensitivity to medicines like Imipenem was a significant cause of the ampC gene of Pseudomonas aeruginosa biofilms (Bagge et al., 2004). By contrast, the way environmental biofilms propagate between biofilm populations and transmit them to free living bacteria is not clearly known, 
generally enhancing their danger of being passed to aquatic microorganisms and possibly humans (Sleytr et al., 2014). An antibiotic micro-acquired organism's resilience is a given capacity to tolerate the genetic resistance effects. However, antibiotic resistance is a transient physiological trait inherited from a population of biofilm cells.

Antibiotic penetration and antibiotic-degrading enzymes accumulation in the biofilm matrix

The whole biofilm matrix is susceptible to antibiotic compounds, which might harm the cells covered. Therefore, the extracellular matrix of polymers defines the volume and antibacterial barrier of the molecule carried over the interior surface of the biofilm. Biofilm EPS (extracellular polymeric substance) offers physical coverage for microorganisms, including proteins, glycoproteins and glycolipids, including several anti-anionic and anti-cationic compounds (Nadell et al., 2015). For example, Pseudomonas aeruginosa biofilms contain the EPS component $\mathrm{Pel}$ exopolysaccharides which can diffuse cationic antibiotics, including aminoglycosides (Colvin et al., 2011). In matrix adsorption sites, the transportation of antimicrobials is also obstructed. The EPS component glycocalyx layer may store up to 25 per cent of its weight and attach to exo-enzymes (Sugano et al., 2016). The lower penetration of antibiotics in elements of the EPS substrate is widely known and does not sufficiently justify higher resistance in biofilmforming microbes to most antibiotics. The effect of decreased antibiotic penetration in biofilm development is unclear as antibiotics that spread biofilm fast contribute to considerable cell death. Reduced antibiotic penetration is hypothesised and leads to a phenotypical adaptive reaction (Tseng et al., 2013). Biofilm bacteria store vast quantities of $\beta$-lactamases as a defence strategy in the biofilm array. In the biofilm matrix Pseudomonas aeruginosa, if $\beta$-lactam is generated, enhanced antibiotic hydrolysis which can contribute to it, including imipenem and ceftazidime. The high promoter activity (ampC $\beta$-lactamases), evaluated using confocal laser pictures, was exhibited by Pseudomonas aeruginosa PAO1-J32 (Bagge et al., 2004); while ampicillin with Klebsiella pneumonia $\beta$-lactamase activity cannot penetrate further into biofilm (Anderl et al., 2000).

\section{Genetic Material of Biofilm}

Extracellular DNA is the main component of the bacterial biofilm matrix. The resistance of some antibiotics against biofilms can be increased by biofilm DNA (Chiang et al., 2013). The fact that DNA improves biofilm resistance is a process that causes external membrane changes since DNA is an anionic molecule that may chelate cations like $\mathrm{Mg} 2+$ ions and reduce $\mathrm{Mg} 2+$ membrane concentration. Pseudomonas aeruginosa and Salmonella enterica $\mathrm{Mg} 2+$ restriction is an environmental signal providing the energy supply of the two-component PhoPQ and PmrAB antimicrobial tolerances (Wilton et al., 2016). These signal molecules are used to reorganise the operon PA3552-3559 (Lewenza et al., 2013). The polyamine in outside mucosa helps preserve the cell by reducing the penetrability from aminoglycosides and cationic peptides that are antibacterial agents of external membrane for positive loading molecules. Spermidine synthera is another route mediated by DNA cation restrictions in Pseudomonas aeruginosa (Johnson et al., 2011). Furthermore, the horizontal transfer of antibiotic resistance genes among bio-filmable microorganism cells has helped as medicines (Hall et al., 2017).

\section{Rate of growth and response to stress}

Oxygen and other nutrient gradient are caused by physiological variability in biofilms throughout their formation. Many antibiotics have effects that are growth dependent. As most antibiotics target a given macromolecular product, the effect of conventional antibiotics on metabolically-inactive or slow-growing cells on the microorganisms in biofilms that limit macromolecular developments is enormous (Öner et al. 2013). A tiny fraction of bacteria can be converted reversibly into constantly growing cells by biofilms. These cells are known as persisting or sleeping cells. These cells are less sensitive to antibiotics than bacteria through a lower rate of metabolism. High amounts of persistent cells are detected in chronic urinary tract infections and lungs in individuals with mucosal fibrosis, especially when the immune system's components are less penetrated. The inactive phenotype is characterised by a downward regulation of processes like energy and biosynthesis. The further creation of DNA toxins/antitoxins (TA) structures is reinforced by 
the usage of environmental conditions or by disruption. TA systems do (i) inhibition of protein syntheses by elongating phosphatic factor; (ii) expression of TA module (i.e. TisB anion channel toxin in a membrane), and (iii) breakdown and inhibition of mRNA (i.e. RelE and MazF). Longlasting Rifampicin aminoglycoside and RNA polymerase treatment can prevent resuscitations with synergistic TA system effects (Keren et al., 2012). It is claimed that fluoroquinolones induce Escherichia coli toxin due to DNA damage TisB (Dorr et al., 2010). Multidrug-resistant cells in biofilms are associated with several TA systems. This immunity is limited to certain antibiotics (Harrison et al., 2009). Bacteria respond to environmental changes in several stresses, including stress oxidative, unanticipated temperature fluctuations, low water, hunger and DNA damage (Stewart et al., 2002).

This adaptive response enhances bacterial survival. Adaptive stress reactions can alter antibiotic sensitivity as such reactions influence many of the same cell and antibiotic processes (Poole et al., 2012). Heterogeneity in biofilm is a source of stress (Stewart et al., 2002). The mitochondrial activity of cells in the hypoxic zones is stagnant and decreased (Stewart et al., 2016). Specific stress mechanisms are thought to cause the bacterial cells to enter steadily. The starvation of nutrients also leads to ppGpp; a global stress reaction called the tight reaction. In Pseudomonas aeruginosa biofilms, the severe reactions and ppGpp signals result in multidrug tolerance. Despite inactivated severe reactions, ofloxacin, gentamicin, meropenem, and colist in killings have proven better (Nguyen et al., 2011). Nutrient starvation also resulted in pathways based on Escherichia coli K-12 biofilm tolerance based on stringent and SOS response (Zheng et al., 2004).

\section{Genetic diversity mediated bacterial resistance}

Biofilms are considered to be a repository for genetic variability. With horizontal gene transfer (HGT), the emergence and spread of antibiotic resistance genes increase in biofilms. In biofilms between microorganism cells, HGT may occur via combining plasmids. In actuality, studies have found that bacterial cell plasmid migrations in biofilms are more effective than planktonic cells, which may be causal to the closeness of planktonic microorganism cells. In addition, certain bacteria may harvest DNA from the biofilm matrix. The highly hydrated matrix provides optimal natural processing conditions (Madsen et al., 2012). The occurrence of antibiotic resistance cassettes is more than 100 times greater in biofilms than in planktonic cells (Strugeon et al., 2016). The mutation level might also be a factor to improve antibiotic resistance or tolerance. Literature has demonstrated that cells in a biofilm are mutated more rapidly and can increase antibiotic resistance than planktonic cells (Wilton et al., 2016).

\section{Multispecies interactions}

Studies show that antimicrobial resistance is substantially more robust in multispecies biofilms than in existing literature in mono species biofilms. A single biofilm species has been demonstrated to be twice as sensitive as Staphylococcus aureus, Enterococcus faecalis or Finegoldia magna in multiple biofilms to gentamicin antibiotics in vivo Pseudomonas aeruginosa. It is uncertain how this biofilm model molecular pathway increases tolerance of gentamycin (Dalton et al., 2011). A clinically relevant multispecies biofilm infection model is Moraxella catarrhalis and Streptococcus pneumonia. These bacteria are characteristic of the pathophysiology of otitis media, a biofilm driven infection that may be persisted several microbial (Dalton et al., 2011). Amoxicillin is extensively used in the treatment of otitis media if antibiotic therapy is needed. However, second-line medicines, such as $\beta$-lactamase inhibitors, are utilised in stubborn conditions in combination with amoxicillin or azithromycin. $M$. catarrhalis creates the $\beta$-lactamase of a biofilm formed of two organisms, giving the tolerance of $S$. pneumonia with amoxicillin (Dalton et al., 2011).

Streptococcus pneumonia prevents unrealised azithromycin Moraxella catarrhalis reciprocally (Perez et al., 2014). As an opportunistic fungal pathogen, Candida albicans and S. aureus show strong resistance to vancomycin in dual-species. The adherence of Candida albicans Als3p in a biofilm comprising Candida albicans and Staphylococcus aureus is associated with fungal hyphae and covered by the biofilm matrix likely to come from Candida albicans and Staphylococcus aureus (Peters et al., 2012). The Staphylococcus aureus resistance to vancomycin is expected to hinder the spread into the biofilm when polymicrobial biofilms are created with Candida 
albicans by the $\beta-1,3$-glucan feature of the fungal substance (Kong et al., 2016). An examination of the two species, Pseudomonas aeruginosa and Stenotrophomonas maltophilia biofilms, discovered that BptS in Pseudomonas aeruginosa, which is the two-component sensor capable of triggering overexpression of both PmrA PA3552-3559 and PA473-4775 regulated genes of the Stenotrophomonas maltophilia intercellular signalling molecule. Both Operon genes have an antibacterial cationic peptide, which has a polymyxin barrier. In actuality, polymyxin $\mathrm{B}$ and colistin sensitivity have been reduced compared to $P$.aeruginosa, a one-species biofilm cultivated in the biofilm with Stenotrophomonas maltophilia (Ryan et al., 2008).

Infections associated with biofilms in the human body

Biofilms cause most chronic and recurring infections in the human body. Planktonic cells are 10-1000 times more resistant to antibiotics than biofilm cells (Mah, 2012). As well as freshwater rivers and rocks, deep-sea vents and hydrothermal hot springs, biofilms may be found in a wide variety of environmental niches. Infections caused by biofilms can be classified into two categories. They can develop on abiotic surfaces, such as medical equipment (Donlan, 2001) and host tissue (native biofilm infections) (Burmolle et al., 2010). The biofilm that forms on medical implants such as heart valves, catheters, contact lenses, joint prostheses, intrauterine devices, and dental units can cause infections of the urinary tract and bloodstream. The only way to cure these infections is to remove the implants, which increases the expense of therapy and creates difficulty for the patients (Costerton et al., 2005). As a result of biofilm infections, host tissue infections are typically persistent, such as cystic fibrosis lung infections, chronic osteomyelitis, chronic prostatitis, chronic sinusitis, chronic otitis media and chronic wounds (Burmolle et al., 2010). Table 2 lists some of the most common biofilm-associated illnesses that cause human disease (Sharma et al., 2019).

\section{Methods for combating biofilm resistance}

Biofilm infections will be processed and distributed by the combination of traditional antibiotics and socalled biofilm disorder. Dissolution from biofilm is the first stage in the ability of the host to eradicate microbial immune system illnesses (Romilly et al., 2014). The combination of antibiotics and biofilm distributing medicines can lead to a favourable outcome. Use alone does not show harmful cells in most biofilm dispersants. However, patulin was not influenced in a particular biofilm by the life of Pseudomonas aeruginosa in order to remove acylhomoserine lactone from it (Rasmussen et al., 2005). Another research has shown that Staphylococcus aureus sensitivity to tigecycline alone has been increased four times in a combination of quorum control chemicals and antibiotic tigecycline (Simonetti et al., 2013). In contrast with an antibiotic alone, cis-2-decanoic acid and ciprofloxacin combinations, Staphylococcus aureus is also raised from 11 to 87 per cent. In view of the rising frequency of antibiotic resistance illnesses, QS inhibitors should be applied in conjunction with the remaining susceptible antibiotics to augment their effects. Antimicrobial mechanisms and molecular processes relating to the development and re-calculation of biofilms can promote better usage of new active substances (Jolivet-Gougeon et al., 2014). Table 1 shows instances of biofilm-specific resistance to antibiotics and tolerances genes (Hall et al., 2017). Alternate approaches to combating the drug resistance of bacterial biofilm communities (Figure 2) have also been investigated in the past.

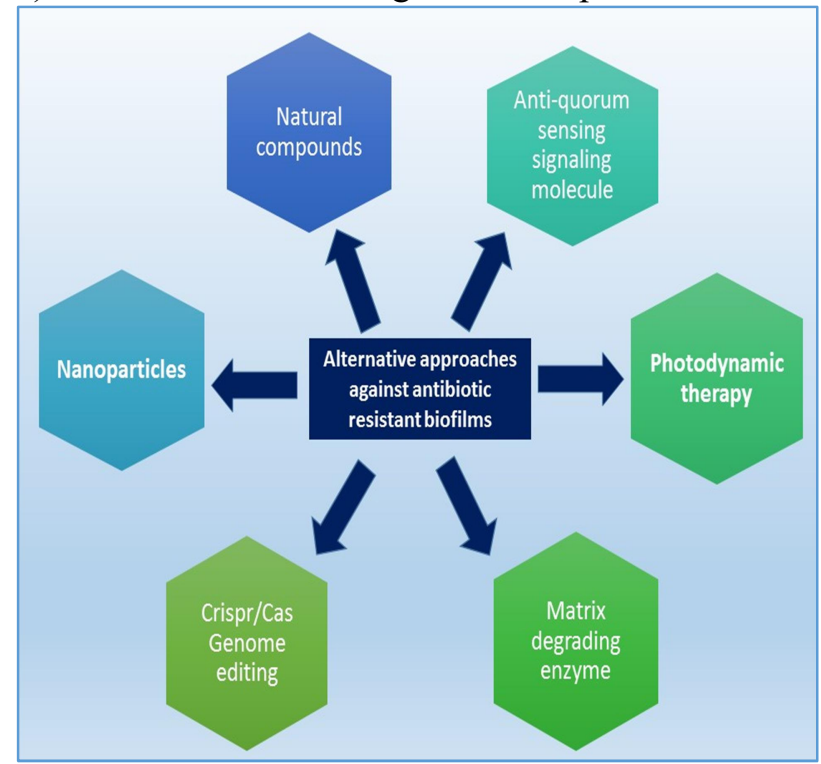

Figure 2: Alternative approaches against biofilm resistance 
These compounds are primarily utilised to suppress In contrast with an antibiotic alone, cis-2-decanoic the QS mechanism, and the antibiotic treatment of acid and ciprofloxacin combinations, these compounds results in far lower dosage Staphylococcus aureus is also raised from 11 to 87 therapy than necessary. per cent. In view of the

Table 1: Antibiotic resistance and tolerance genes unique to biofilm

\begin{tabular}{|c|c|c|c|}
\hline Microorganisms & Antibiotics & Genes & Products of genes \\
\hline \multirow[t]{8}{*}{$\begin{array}{l}\text { Pseudomonas } \\
\text { aeruginosa }\end{array}$} & $\begin{array}{l}\text { Tobramycin, norfloxacin, trimethoprim, } \\
\text { tetracycline, kanamycin, chloramphenicol }\end{array}$ & brlR & Regulators of transcription \\
\hline & Tobramycin, norfloxacin & sagS & $\begin{array}{l}\text { Two-component hybrid } \\
\text { system }\end{array}$ \\
\hline & Tobramycin, gentamicin, ciprofloxacin & ndvB & Glucosyltransferase \\
\hline & Tobramycin & $\begin{array}{l}\text { exaA, pqqC, } \\
\text { erbR }\end{array}$ & Ethanol oxidation \\
\hline & $\begin{array}{l}\text { Tobramycin, gentamicin, } \\
\text { ciprofloxacin }\end{array}$ & PA1875-1877 & Antibiotic efflux pump \\
\hline & $\begin{array}{l}\text { Tobramycin, gentamicin, } \\
\text { ciprofloxacin }\end{array}$ & tssC1, hcp 1 & $\begin{array}{l}\text { Type VI secretion } \\
\text { components }\end{array}$ \\
\hline & Tobramycin, gentamicin & PA0756-0757 & Two-component system \\
\hline & $\begin{array}{l}\text { Ofloxacin, meropenem, } \\
\text { colistin, gentamicin }\end{array}$ & relA, spoT & Stringent response \\
\hline \multirow[t]{2}{*}{ Escherichia coli } & $\begin{array}{l}\text { Penicillin G, norfloxacin, } \\
\text { chloramphenicol, gentamicin }\end{array}$ & $\operatorname{rap} \mathrm{A}$ & Helicase-like protein \\
\hline & Tobramycin, cefazolin & yafQ & Toxin \\
\hline \multirow[t]{3}{*}{$\begin{array}{l}\text { Enterococcus } \\
\text { faecalis }\end{array}$} & Gentamicin, Daptomycin & epaOX, epaI & Glycolsyltranferase \\
\hline & Gentamicin, daptomycin, linezolid & gelE & Gelatinase \\
\hline & Gentamicin, daptomycin, linezolid & fsrA, fsrC & Quorum-sensing \\
\hline $\begin{array}{l}\text { Streptococcus } \\
\text { mutans }\end{array}$ & Gentamicin & dltABCD & $\begin{array}{l}\text { D-alanylation of teichoic } \\
\text { acid }\end{array}$ \\
\hline
\end{tabular}

Table 2. Infections linked with biofilms and their adhering surfaces

\begin{tabular}{|c|c|c|}
\hline Infection in human & Surface of the infection & Species of the bacteria \\
\hline $\begin{array}{l}\text { Endocarditis and Root canal } \\
\text { infection }\end{array}$ & $\begin{array}{l}\text { Urinary catheters, Heart valves, } \\
\text { Central venous catheters and Tooth }\end{array}$ & Enterococcus faecalis \\
\hline Endocarditis & Tooth and Vascular grafts & Streptococcus mutans \\
\hline $\begin{array}{l}\text { Otitis media, Cystic fibrosis and } \\
\text { Nosocomial infection }\end{array}$ & $\begin{array}{l}\text { Middle ear, Prostheses, Central } \\
\text { venous Catheters and Lungs }\end{array}$ & Pseudomonas aeruginosa \\
\hline Tuberculosis & Lungs & Mycobacterium tuberculosis \\
\hline $\begin{array}{l}\text { Pneumonia, Infection in } \\
\text { Respiratory tract and Urinary } \\
\text { tract and Pyogenic liver abscess }\end{array}$ & Liver and Lungs & Klebsiella pneumonia \\
\hline $\begin{array}{l}\text { Urinary tract infection, Otitis } \\
\text { media and Bacterial prostatitis }\end{array}$ & $\begin{array}{l}\text { Prostheses, Urinary tract } \\
\text { Urinary catheters and Middle ear }\end{array}$ & Escherichia coli \\
\hline Otitis media & Middle ear & Haemophilus influenza \\
\hline Cystic fibrosis & Lungs & Burkholderia cepacia \\
\hline
\end{tabular}

rising frequency of antibiotic resistance illnesses, QS inhibitors should be applied in conjunction with the remaining susceptible antibiotics to augment their effects. These compounds are primarily utilised to suppress the QS mechanism, and the antibiotic treatment of these compounds results in far lower dosage therapy than necessary. New diguanylate cyclase enzyme inhibitors were discovered by silicone scanning and tested satisfactorily in vitro. For in vivo testing to 
augment the antibacterial action, flow pump inhibitors may also be administered. Also, it is vital to choose and disrupt antimicrobial agents because some may act as agonists for biofilms production. Usage and use of novel antibiotics and therapeutically synthesised antibiotics should be evaluated, and the affecting concentrations should be investigated for their function in biofilm and for adverse effects from signalling molecules. In the manufacture of these signalling molecules, the other substances work as necessary enzymes to govern the virulence and biofilm component development. New inhibitors might be found by a technique centred on the ligand.

\section{Conclusion}

Biofilm infections are particularly resistant to antibiotics and physical treatment, and there are numerous ways to enhance antibiotic film biofilm resistance and tolerance, including persistent cells, adaptive responses and lower penetration of antibiotics. Antibiotic tolerance and the paths to resistance in biofilms are generally recognised as genetically determined. In the case of human illnesses, highly organised cells are leading to immune responses that cause tissue loss and lifelong illnesses. Exploring prospective cures for

\section{References}

Anderl, J. N., Franklin, M. J., \& Stewart, P. S. (2000). Role of antibiotic penetration limitation in Klebsiella pneumoniae biofilm resistance to ampicillin and ciprofloxacin. Antimicrobial agents and chemotherapy, 44(7), 1818-1824.

Bagge, N., Hentzer, M., Andersen, J. B., Ciofu, O., Givskov, M., \& Høiby, N. (2004). Dynamics and spatial distribution of $\beta$-lactamase expression in Pseudomonas aeruginosa biofilms. Antimicrobial agents and chemotherapy, 48(4), 1168-1174.

Barge, N., Schuster, M., Hentzer, M., Ciofu, O., Givskov, M., Greenberg, E. P., \& Høiby, N. (2004). Pseudomonas aeruginosa biofilms exposed to imipenem exhibit changes in global gene expression and $\beta$-lactamase and alginate production. Antimicrobial agents and chemotherapy, 48(4), 1175-1187.

Baquero, F., Martínez, J. L., \& Cantón, R. (2008). Antibiotics and antibiotic resistance in water environments. Current opinion in biotechnology, 19(3), 260-265. biofilm-related illnesses is a significant problem. Few new and successful antibiotic strategies have been explored, including biofilm dispersions, quorum-sensing inhibitor antibiotic formulation, and many recent techniques. Although the aforementioned antibiotic film techniques are essential fields of study, they have not been clinically researched and reached the market. Biofilms are produced in almost every submerged region of natural and human-made systems to ensure that bacterial species grow, actively interact with one other in an adequate and ideal habitat. More study is nevertheless needed to identify how significant health risks may arise in the hot zones of antibiotic resistance and how the different biofilm compartments are changing the movement of this pool of genetic resistance in the bacterial communities. The ongoing development and availability of specific, well-cured database technologies (e.g. metagenomics, metatranscriptomics) and bioinformatics technology will contribute to achieve this goal. By discussing these questions would offer a more accurate insight into ecological transmission pathways for resistance genes in biofilms to offer a clearer view of antibiotic resistance and its risk for the environment and human health.

Burmolle, M., Thomsen, T. R., Fazli, M., Dige, I., Christensen, L., Homøe, P., \& Bjarnsholt, T. (2010). Biofilms in chronic infections-a matter of opportunity-monospecies biofilms in multispecies infections. FEMS Immunology \& Medical Microbiology, 59(3), 324-336.

Chiang, W. C., Nilsson, M., Jensen, P. Ø., Høiby, N., Nielsen, T. E., Givskov, M., \& Tolker-Nielsen, T. (2013). Extracellular DNA shields against aminoglycosides in Pseudomonas aeruginosa biofilms. Antimicrobial agents and chemotherapy, 57(5), 2352-2361.

Chrisman, C. J., Albuquerque, P., Guimaraes, A. J., Nieves, E., \& Casadevall, A. (2011). Phospholipids trigger Cryptococcus neoformans capsular enlargement during interactions with amoebae and macrophages. PLoS Pathogens, 7(5), e1002047.

Costerton, J. W., Montanaro, L., \& Arciola, C. R. (2005). Biofilm in implant infections: its production and regulation. The International journal of artificial organs, 28(11), 1062-1068.

Donlan, R. M. (2001). Biofilms and device-associated infections. Emerging infectious diseases, 7(2), 277. 
Dörr, T., Vulić, M., \& Lewis, K. (2010). Ciprofloxacin causes persister formation by inducing the TisB toxin in Escherichia coli. PLoS Biology, 8(2), e1000317.

Gebreyohannes, G., Nyerere, A., Bii, C., \& Sbhatu, D. B. (2019). Challenges of intervention, treatment, and antibiotic resistance of biofilm-forming microorganisms. Heliyon, 5(8), e02192.

Gilbert, P., Maira-Litran, T., McBain, A. J., Rickard, A. H., \& Whyte, F. W. (2002). The physiology and collective recalcitrance of microbial biofilm communities.

Grainha, T., Magalhães, A. P., Melo, L. D., \& Pereira, M. O. (2020). Pitfalls associated with discriminating mixedspecies biofilms by flow cytometry. Antibiotics, 9(11), 741 .

Hall, C. W., \& Mah, T. F. (2017). Molecular mechanisms of biofilm-based antibiotic resistance and tolerance in pathogenic bacteria. FEMS microbiology reviews, 41(3), 276-301.

Harrison, J. J., Wade, W. D., Akierman, S., Vacchi-Suzzi, C., Stremick, C. A., Turner, R. J., \& Ceri, H. (2009). The chromosomal toxin gene yafQ is a determinant of multidrug tolerance for Escherichia coli growing in a biofilm. Antimicrobial agents and chemotherapy, 53(6), 2253-2258.

Hathroubi, S., Mekni, M. A., Domenico, P., Nguyen, D., \& Jacques, M. (2017). Biofilms: microbial shelters against antibiotics. Microbial Drug Resistance, 23(2), 147-156.

Johnson, L., Mulcahy, H., Kanevets, U., Shi, Y., \& Lewenza, S. (2012). Surface-localised spermidine protects the Pseudomonas aeruginosa outer membrane from antibiotic treatment and oxidative stress. Journal of bacteriology, 194(4), 813-826.

Jolivet-Gougeon, A., \& Bonnaure-Mallet, M. (2014). Biofilms as a mechanism of bacterial resistance. Drug Discovery Today: Technologies, 11, 49-56.

Karthik, L., Kumar, G., Keswani, T., Bhattacharyya, A., Chandar, S. S., \& Rao, K. B. (2014). Protease inhibitors from marine actinobacteria as a potential source for antimalarial compound. PloS one, 9(3), e90972.

Keren, I., Mulcahy, L. R., \& Lewis, K. (2012). Persister eradication: lessons from the world of natural products. Methods in enzymology, 517, 387-406.

Kong, E. F., Tsui, C., Kucharíková, S., Andes, D., Van Dijck, P., \& Jabra-Rizk, M. A. (2016). Commensal protection of Staphylococcus aureus against antimicrobials by Candida albicans biofilm matrix. MBio, 7(5).

Lewenza, S. (2013). Extracellular DNA-induced antimicrobial peptide resistance mechanisms in Pseudomonas aeruginosa. Frontiers in microbiology, 4, 21.
Madsen, J. S., Burmølle, M., Hansen, L. H., \& Sørensen, S. J. (2012). The interconnection between biofilm formation and horizontal gene transfer. FEMS Immunology \& Medical Microbiology, 65(2), 183-195.

Mah, T. F. (2012). Biofilm-specific antibiotic resistance. Future microbiology, 7(9), 1061-1072.

Mangwani, N., Kumari, S., \& Das, S. (2016). Bacterial biofilms and quorum sensing: fidelity in bioremediation technology. Biotechnology and Genetic Engineering Reviews, 32(1-2), 43-73.

Nadell, C. D., Drescher, K., Wingreen, N. S., \& Bassler, B. L. (2015). Extracellular matrix structure governs invasion resistance in bacterial biofilms. The ISME journal, 9(8), 1700-1709.

Nguyen, D., Joshi-Datar, A., Lepine, F., Bauerle, E., Olakanmi, O., Beer, K., ... \& Singh, P. K. (2011). Active starvation responses mediate antibiotic tolerance in biofilms and nutrient-limited bacteria. Science, 334(6058), 982-986.

Öner, E. T. (2013). Microbial production of extracellular polysaccharides from biomass. In Pretreatment techniques for biofuels and biorefineries (pp. 35-56). Springer, Berlin, Heidelberg.

Perez, A. C., Pang, B., King, L. B., Tan, L., Murrah, K. A., Reimche, J. L., \& Swords, W. E. (2014). Residence of Streptococcus pneumoniae and Moraxella catarrhalis within polymicrobial biofilm promotes antibiotic resistance and bacterial persistence in vivo. Pathogens and disease, 70(3), 280-288.

Peters, B. M., Ovchinnikova, E. S., Krom, B. P., Schlecht, L. M., Zhou, H., Hoyer, L. L., \& Shirtliff, M. E. (2012). Staphylococcus aureus adherence to Candida albicans hyphae is mediated by the hyphal adhesin Als3p. Microbiology, 158(Pt 12), 2975.

Poole, K. (2012). Bacterial stress responses as determinants of antimicrobial resistance. Journal of Antimicrobial Chemotherapy, 67(9), 2069-2089.

Rasmussen, T. B., Skindersoe, M. E., Bjarnsholt, T., Phipps, R. K., Christensen, K. B., Jensen, P. O., \& Givskov, M. (2005). Identity and effects of quorum-sensing inhibitors produced by Penicillium species. Microbiology, 151(5), $1325-1340$.

RegBott T. (2011). Industrial biofouling. In: Biofilms in Industry. Edgbaston, UK: Elsevier Inc.; pp. 181-201.

Robertson, S. R., \& McLean, R. J. (2015). Beneficial biofilms. AIMS Bioengineering, 2(4), 437-448.

Romanı, A. M. (2010). Freshwater biofilms. Biofouling. WileyBlackwell, Oxford, 137-153.

Ryan, R. P., Fouhy, Y., Garcia, B. F., Watt, S. A., Niehaus, K., Yang, L., \& Dow, J. M. (2008). Interspecies signalling via 
the Stenotrophomonas maltophilia diffusible signal factor influences biofilm formation and polymyxin tolerance in Pseudomonas aeruginosa. Molecular microbiology, 68(1), 75-86.

Sabater, S., Guasch, H., Ricart, M., Romaní, A., Vidal, G., Klünder, C., \& Schmitt-Jansen, M. (2007). Monitoring the effect of chemicals on biological communities. The biofilm as an interface. Analytical and bioanalytical chemistry, 387(4), 1425-1434.

Sambanthamoorthy, K., Luo, C., Pattabiraman, N., Feng, X., Koestler, B., Waters, C. M., \& Palys, T. J. (2014). Identification of small molecules inhibiting diguanylate cyclases to control bacterial biofilm development. Biofouling, 30(1), 17-28.

Sehrawat, S., Reddy, P. B., Rajasagi, N., Suryawanshi, A., Hirashima, M., \& Rouse, B. T. (2010). Galectin-9/TIM-3 interaction regulates virus-specific primary and memory CD8+ T cell response. PLoS Pathogens, 6(5), e1000882.

Sharma, D., Misba, L., \& Khan, A. U. (2019). Antibiotics versus biofilm: an emerging battleground in microbial communities. Antimicrobial Resistance \& Infection Control, 8(1), 1-10.

Shenkutie, A. M., Yao, M. Z., Siu, G. K. H., Wong, B. K. C., \& Leung, P. H. M. (2020). Biofilm-induced antibiotic resistance in clinical acinetobacter baumannii isolates. Antibiotics, 9(11), 817.

Simon, M., \& Grossart, H. P., Schweitzer, B., and Ploug, H. 2002. Microbial ecology of organic aggregates in aquatic ecosystems. Aquatic Microbial Ecology, 28, 175-211.

Simonetti, O., Cirioni, O., Mocchegiani, F., Cacciatore, I., Silvestri, C., Baldassarre, L., \& Offidani, A. (2013). The efficacy of the quorum sensing inhibitor FS8 and tigecycline in preventing prosthesis biofilm in an animal model of staphylococcal infection. International journal of molecular sciences, 14(8), 16321-16332.

Sleytr, U. B., Schuster, B., Egelseer, E. M., \& Pum, D. (2014). S-layers: principles and applications. FEMS microbiology reviews, 38(5), 823-864.

Stewart, P. S., Zhang, T., Xu, R., Pitts, B., Walters, M. C., Roe, F., \& Moter, A. (2016). Reaction-diffusion theory explains hypoxia and heterogeneous growth within microbial biofilms associated with chronic infections. npj Biofilms and Microbiomes, 2(1), 1-8.

Strugeon, E., Tilloy, V., Ploy, M. C., \& Da Re, S. (2016). The stringent response promotes antibiotic resistance dissemination by regulating integron integrase expression in biofilms. MBio, 7(4).

Sugano, M., Morisaki, H., Negishi, Y., Endo-Takahashi, Y., Kuwata, H., Miyazaki, T., \& Yamamoto, M. (2016). Potential effect of cationic liposomes on interactions with oral bacterial cells and biofilms. Journal of liposome research, 26(2), 156-162.

Teschler, J. K., Zamorano-Sánchez, D., Utada, A. S., Warner, C. J., Wong, G. C., Linington, R. G., \& Yildiz, F. H. (2015). Living in the matrix: assembly and control of Vibrio cholerae biofilms. Nature Reviews Microbiology, 13(5), 255-268.

Tseng, B. S., Zhang, W., Harrison, J. J., Quach, T. P., Song, J. L., Penterman, J., ... \& Parsek, M. R. (2013). The extracellular matrix protects $\mathrm{P}$ seudomonas aeruginosa biofilms by limiting the penetration of tobramycin. Environmental microbiology, 15(10), 28652878.

Uruén, C., Chopo-Escuin, G., Tommassen, J., Mainar-Jaime, R. C., \& Arenas, J. (2021). Biofilms as promoters of bacterial antibiotic resistance and tolerance. Antibiotics, 10(1), 3 .

Wilton, M., Charron-Mazenod, L., Moore, R., \& Lewenza, S. (2016). Extracellular DNA acidifies biofilms and induces aminoglycoside resistance in Pseudomonas aeruginosa. Antimicrobial agents and chemotherapy, 60(1), 544-553.

Wimpenny, J., Manz, W., \& Szewzyk, U. (2000). Heterogeneity in biofilms. FEMS microbiology reviews, 24(5), 661-671.

Wingender, J., Szewzyk, U., Steinberg, P., Rice, S. A., \& Kjelleberg, S. (2016). Biofilms: an emergent form of bacterial life. Nature Review Microbiology, 14(9), 563-575.

Zhang, L., \& Mah, T. F. (2008). Involvement of a novel efflux system in biofilm-specific resistance to antibiotics. Journal of bacteriology, 190(13), 4447-4452. 